\title{
HBV and HCV genotypes distribution on the territory of Belarus
}

\author{
EL Gasich, VF Eremin*, SV Sasinovich, MG Tulinova \\ From 17th International Symposium on HIV and Emerging Infectious Diseases (ISHEID) \\ Marseille, France. 23-25 May 2012
}

\section{Materials and methods}

$236 \mathrm{HCV}$ and $158 \mathrm{HBV}$ plasma samples collected during 2004-2011 have been investigated. EIA, PCR, RT-PCR, sequencing, SeqScape, BioEdit, MEGA4.1, statistica v.6 software have been used.

\section{Results}

Of 158 HBV HBsAg positive specimens 17 (10,8\%) were from patients with acute hepatitis B and 141 (89,2\%) from chronic hepatitis B. Among surveyed were 83 $(43,6 \%)$ women and $92(56,4 \%)$ men at the age from 15 till 90 years. Middle age has made $44,5 \pm 17,8$ years. From 158 surveyed 11 persons have been $\mathrm{HBV}+\mathrm{HBC}$ co-infected and 1 with HBV+HCV+HIV. HBV genotypes has been defined at $61(34,9 \%)$ patient. The phylogenetic analysis of HBV preS fragment has shown that in $52(85,3 \%)$ cases come to light D genotype (D1 $32.9 \%$; D2 - 26,2\%, D3 - 26.2\%), in 7 (11,5\%) - A (A2) and in $2(3,2 \%)-\mathrm{C}(\mathrm{C} 2)$ genotype. Of $236 \mathrm{HCV}$ infected patients prevailed $1 \mathrm{~b}(53,8 \%, \mathrm{n}=127)$ and $3 \mathrm{a}$ $(28,8 \%, \mathrm{n}=58)$ genotypes. At $30(12.7 \%)$ cases have been revealed $1 \mathrm{a}$ genotype and $2 \mathrm{a}$ and $2 \mathrm{~b}$ genotypes have been revealed in $8(3,4 \%)$ and $3(1,3 \%)$ cases accordingly.

\section{Conclusion}

In the territory of Belarus a genetic variety of HBV and HCV genotypes, caused both circulation before the brought viruses, and new drifts from neighbouring countries, basically from Russia and Ukraine is observed.

Published: 25 May 2012

* Correspondence: veremin@mail.ru Briem, Minsk, Belarus

C Biomed Central

@ 2012 Gasich et al; licensee BioMed Central Ltd. This is an Open Access article distributed under the terms of the Creative Commons Attribution License (http://creativecommons.org/licenses/by/2.0), which permits unrestricted use, distribution, and reproduction in any medium, provided the original work is properly cited.
doi:10.1186/1742-4690-9-S1-P57

Cite this article as: Gasich et al:: HBV and HCV genotypes distribution

on the territory of Belarus. Retrovirology 2012 9(Suppl 1):P57.
Submit your next manuscript to BioMed Central and take full advantage of:

- Convenient online submission

- Thorough peer review

- No space constraints or color figure charges

- Immediate publication on acceptance

- Inclusion in PubMed, CAS, Scopus and Google Scholar

- Research which is freely available for redistribution 